\title{
The Effects of Zinc Treatment on the Blood-Brain Barrier Permeability and Brain Element Levels During Convulsions
}

\author{
Hatice Yorulmaz • Fatma Burcu Șeker • Göksel Demir • \\ İbrahim Ertuğrul Yalçın • Baria Öztaș
}

Received: 11 May 2012 / Accepted: 8 November 2012 /Published online: 24 November 2012

(C) The Author(s) 2012. This article is published with open access at Springerlink.com

\begin{abstract}
We evaluated the effect of zinc treatment on the blood-brain barrier (BBB) permeability and the levels of zinc $(\mathrm{Zn})$, natrium $(\mathrm{Na})$, magnesium $(\mathrm{Mg})$, and copper $(\mathrm{Cu})$ in the brain tissue during epileptic seizures. The Wistar albino rats were divided into four groups, each as follows: (1) control group, (2) pentylenetetrazole (PTZ) group: rats treated with PTZ to induce seizures, (3) Zn group: rats treated with $\mathrm{ZnCl}_{2}$ added to drinking water for 2 months, and (4) Zn+PTZ group. The brains were divided into left, right hemispheres, and cerebellum+brain stem regions. Evans blue was used as BBB tracer. Element concentrations were analyzed by inductively coupled plasma optical emission spectroscopy. The BBB permeability has been found to be increased in all experimental groups $(p<0.05)$. Zn concentrations in all brain regions in $\mathrm{Zn}$-supplemented groups $(p<0.05)$ showed an increase. BBB permeability and $\mathrm{Zn}$ level in cerebellum+brain stem region were significantly high compared to cerebral hemispheres $(p<0.05)$. In all experimental groups, $\mathrm{Cu}$ concentration decreased, whereas $\mathrm{Na}$ concentrations showed an increase $(p<0.05)$. Mg content in all the brain regions decreased in the $\mathrm{Zn}$ group and $\mathrm{Zn}+$ PTZ groups compared to other groups $(p<0.001)$. We also
\end{abstract}

H. Yorulmaz $(\bowtie)$

Halic University School of Nursing, Halic University,

Büyükdere Avenue. Number: 101, Mecidiyeköy,

34394 Istanbul, Turkey

e-mail: haticeyorulmaz@hotmail.com

F. B. Șeker

Faculty of Medicine, Yeditepe University, Istanbul, Turkey

G. Demir $\cdot$ İ. E. Yalçın

Engineering Faculty, Environmental Engineering Department,

Bahcesehir University, Istanbul, Turkey

B. Öztaş

Istanbul Faculty of Medicine, Istanbul University, Istanbul, Turkey found that all elements' levels showed hemispheric differences in all groups. During convulsions, $\mathrm{Zn}$ treatment did not show any protective effect on BBB permeability. Chronic $\mathrm{Zn}$ treatment decreased $\mathrm{Mg}$ and $\mathrm{Cu}$ concentration and increased $\mathrm{Na}$ levels in the brain tissue. Our results indicated that $\mathrm{Zn}$ treatment showed proconvulsant activity and increased BBB permeability, possibly changing prooxidant/antioxidant balance and neuronal excitability during seizures.

Keywords Blood-brain barrier · Convulsions · Elements · Zinc

\section{Introduction}

The blood-brain barrier (BBB) protects the brain from the toxic substances in the blood and ensures constant supply of nutrients for neurons. But BBB structure could break down in certain conditions like convulsive seizures [1]. In addition, it was shown that asymmetrical changes in blood brain barrier permeability between hemispheres and cerebellum+ brain stem regions during pentylenetetrazol induced seizures in rats [2].

Epileptic seizures strongly modify internal conditions within the nervous tissue. There are many changes in neurotransmitter release, gene activation, and elemental composition [3].

Moreover, it was reported that trace element concentrations like magnesium $(\mathrm{Mg})$, zinc $(\mathrm{Zn})$, copper $(\mathrm{Cu})$, and iron $(\mathrm{Fe})$ concentrations show changes during epileptic seizures. Element contents determine susceptibility to convulsions [4].

BBB is important for $\mathrm{Zn}$ homeostasis in the brain. Deficiency or excess of $\mathrm{Zn}$ has been shown to contribute to alterations in behavior, abnormal central nervous system development, and neurological disease [5]. $\mathrm{Zn}$ is a component of more than 300 different enzymes that function in many aspects of cellular metabolism, involving metabolism 
of proteins, lipids, and carbohydrates. The brain contains a high concentration of $\mathrm{Zn}$. It serves as a mediator of cell-cell signalling in the central nervous system and alters behavior of channels and receptors [6]. Zn passes into portal blood and is transported. The transport of $\mathrm{Zn}$ into the brain parenchyma occurs via the brain barrier system, i.e., the BBBcerebrospinal fluid barriers. Studies in the hippocampus, amygdala, and neocortex revealed that these neurons in the forebrain represent a subgroup of excitatory glutamatergic neurons called nowadays as gluzinergic neurons [7, 8]. Neurons that contain free $\mathrm{Zn}$ ions in the vesicles of their presynaptic boutons are present also in other brain areas and are generally termed $\mathrm{Zn}$-enriched (ZEN) neurons. In the spinal cord, it has been proven that the majority of $\mathrm{ZEN}$ terminals are inhibitory g-aminobutyric acid (GABA)-ergic, and only a minor pool is glutaminergic [9]. Glycinergic ZEN neurons in the spinal cord have also been described, and recently, the presence of GABAergic ZEN terminals has been found in the cerebellum [10]. Releasable, vesicular Zn is most abundant in brain regions that are prone to seizures, namely the limbic regions. Potential roles for synaptic released $\mathrm{Zn}$ include inhibition of NMDA receptors, potentiation of AMPA receptor responses, inhibition epileptics, in which plasma $\mathrm{Mg}$ concentrations decreased of $\mathrm{GABA}_{\mathrm{A}}$ receptors that lack $\gamma$ subunits, and antagonism of voltagegated calcium channels. Thus, as a potential neuromodulator, $\mathrm{Zn}$ is capable of exerting effects that could either inhibit or promote neuronal excitability, suggesting the possibility of both pro- and anticonvulsant properties [7, 11].

Therefore, $\mathrm{Zn}$ homeostasis in the brain may be important for the development of seizures. In some studies, $\mathrm{Zn}$ showed anticonvulsant effect, although $\mathrm{Zn}$ has a proconvulsant effect depending on the type of seizure, animal species, and convulsant agents [12, 13]. Systemic charges of $\mathrm{Zn}$ have shown anticonvulsant property in several experimental models [12].

Lynes et al. characterized $\mathrm{Zn}$ as an agent modifying reactive oxygen species activation, increasing oxidative activity of NADPH, and consequently, triggering oxidative stress [14]. $\mathrm{Zn}$ is also cofactors of some antioxidant enzymes such as superoxide dismutase and catalase [15]. It was found that the development of such attacks is related to oxidative stress within the brain In addition, oxidative stress represents one of the crucial factors providing greater BBB permeability values during epileptic seizures [16]. Therefore, antioxidant levels may be important during seizures

The effect of $\mathrm{Zn}$ treatment on convulsions is controversial, and its effect on the BBB permeability is not known. Seizure activity in epileptic patients and experimental models of epilepsy influence the metabolism of essential trace elements, e.g., $\mathrm{Zn}, \mathrm{Fe}, \mathrm{Cu}$, and $\mathrm{Mg}$ in the brain and peripheral tissues [5]. It is important to show whether the concentration of essential elements in the brain is altered by enhancement of susceptibility to seizures or epileptic neuronal activity. For these reasons, the aim of the present study was to investigate the role of chronic $\mathrm{Zn}$ treatment on the BBB permeability in pentylenetetrazole (PTZ)-induced seizures and levels of other elements in the different brain regions.

\section{Materials and Methods}

Animals

The experimental procedure was in accordance with the Helsinki Declaration (2004). The 32 Wistar albino rats were divided into four groups as follows: (1) control group, (2) pentylenetetrazole (Sigma Cat no. P6500) group: rats treated with PTZ (80 mg/kg, i.v.) to induce epileptic seizures, (3) Zn group: rats treated with $\mathrm{ZnCl}_{2} 227 \mathrm{ml} / \mathrm{kg}$ [17] added to drinking water for 2 months, and (4) Zn+PTZ group. Cannulations of the femoral artery and vein were performed in animals. The blood pressure was measured from the femoral artery. PTZ and Evans blue were injected from the femoral vein. Because most anesthetics have anticonvulsant properties, diethyl ether anesthesia was used.

\section{Assessment of Blood-Brain Barrier Permeability}

Evans Blue (Sigma Cat no. E-2129) was used as BBB tracer (4 ml/kg, i.v.). PTZ was i.v. injected in order to induce convulsions, 5 min after Evans Blue injection. The brains were elutriated by perfusion with $0.9 \% \mathrm{NaCl}$ solution via the left ventricle $25 \mathrm{~min}$ after Evans Blue injection. Then, the brains were dissected and separated into the left hemisphere, right hemisphere, and cerebellum + brainstem regions. Wet masses of the dissected samples were measured. Afterwards, each brain region was homogenized by placing in tubes with phosphate buffer $(2.5 \mathrm{ml})$. A $60 \%$ solution of trichloroacetic acid $(2.5 \mathrm{ml})$ was put in each tube after homogenizing; this procedure provided separation of Evans Blue from albumin by vortexing for $2 \mathrm{~min}$. After the vortex process, the tubes were kept at $4{ }^{\circ} \mathrm{C}$ for $30 \mathrm{~min}$ and centrifuged at $1,000 \times g$ at $4{ }^{\circ} \mathrm{C}$ for $30 \mathrm{~min}$. After centrifuging, the absorbance values were read spectrophotometrically at $620 \mathrm{~nm}$ wavelength (after decanting supernatants to spectrophotometer tubes). The Evans Blue content values (micrograms per milligram tissue) were calculated for brain tissue samples using the Evans Blue absorbance-quantity regression equation and catenary via the obtained absorbance values. The statistical analysis was made with SPSS (Statistical Package for Social Sciences 16.0 version).

Measurement of Element Concentrations

Samples of $0.2 \mathrm{~g}$. were taken and transferred into Teflon vessels and then $10 \mathrm{ml}$ of $20 \%$ HNO3 (Merck) was added. 
Samples were mineralized in a microwave oven (BerghofMWS2) as follows: at $145^{\circ} \mathrm{C}$ for $5 \mathrm{~min}$, at $165^{\circ} \mathrm{C}$ for $5 \mathrm{~min}$, and at $175{ }^{\circ} \mathrm{C}$ for $20 \mathrm{~min}$. After cooling, the samples were filtered by Whatman filters, and filled up to $50 \mathrm{ml}$ with ultrapure water in volumetric flasks and then stored in falcon tubes. Standard solutions were prepared by using multi-element stock solutions-1,000 ppm (Merck), and element $(\mathrm{Cu}, \mathrm{Mg}, \mathrm{Na}$, and $\mathrm{Zn})$ measurements were done by inductively coupled plasma optical emission spectroscopy (PerkinElmer-Optima 7000 DV).

\section{Statistical Analysis}

The obtained data were analyzed with SPSS (version 17.0) statistics program. Evans Blue-albumin extravasation, arterial pressure, and element concentration were expressed as mean \pm standard deviation. Data were compared among groups and brain regions using one-way analysis of variance and subsequently Tukey's test was performed $(P<0.05)$.

\section{Results}

Systolic and diastolic blood pressures are shown in Table 1. PTZ-induced convulsions caused a significant increase in the blood pressure in groups 2 and $4(P<0.001)$.

In control animals (group 1), the mean Evans Blue concentrations in both cerebral hemispheres and in the cerebellum+brainstem regions were $0.31 \pm 0.09,0.31 \pm 0.08,0.37 \pm$ 0.07 (mean $\pm \mathrm{SD}$ ) $\mu \mathrm{g} / \mathrm{mg}$ tissue, respectively. The BBB permeability increased significantly in the PTZ group [0.62 \pm $0.15,0.65 \pm 0.11,0.88 \pm 0.18$ (mean $\pm \mathrm{SD}) \mu \mathrm{g} / \mathrm{mg}$ tissue, respectively]. The mean Evans Blue concentration in the $\mathrm{Zn}$ group is $[0.42 \pm 0.06,0.47 \pm 0.14,0.76 \pm 0.10($ mean $\pm \mathrm{SD}) \mu \mathrm{g} /$ $\mathrm{mg}$ tissue, respectively] and $[0.72 \pm 0.11,0.70 \pm 0.13,0.75 \pm$ 0.16 (mean $\pm \mathrm{SD}$ ) $\mu \mathrm{g} / \mathrm{mg}$ tissue, respectively] in the $\mathrm{Zn}+\mathrm{PTZ}$ groups $(P<0.05$ and $P<0.01$; Fig. 1$)$.

There was no significant difference between the control and $\mathrm{Zn}+\mathrm{PTZ}$ groups $(P>0.05)$. In both the $\mathrm{Zn}$ and PTZ groups, the mean Evans Blue concentration of cerebellum + brainstem increased compared to cerebral hemispheres $(P<0.05, P<0.01$, and $P<0.001$; Fig. 1$)$.

$\mathrm{Zn}$ concentrations were significantly increased in all brain regions and in all groups compared to control group $(P<0.01$ and $P<0.05)$. Additionally, it increased in all the brain regions of the $\mathrm{Zn}+\mathrm{PTZ}$ group compared to $\mathrm{PTZ}$ and $\mathrm{Zn}$ groups $(P<0.05$; Fig. 2$)$.

$\mathrm{Zn}$ concentration of cerebellum +brainstem significantly increased when compared to right hemisphere in the control group $(P<0.05)$. It was significantly high in brain hemispheres when compared to cerebellum+brainstem $(P<0.01)$, and also, $\mathrm{Zn}$ concentration of the left hemisphere was significantly higher than the right hemisphere $(P<0.05)$.

$\mathrm{Zn}$ concentration of the left hemisphere in $\mathrm{Zn}$ group was higher than the cerebellum+brainstem and right hemisphere $(P<0.05$ and $P<0.01)$. In the $\mathrm{Zn}$ and PTZ groups, $\mathrm{Zn}$ concentration of the left and right hemispheres increased compared to cerebellum + brainstem regions $(P<0.05$ and $P<0.01$; Fig. 2).

Significant increases of $\mathrm{Na}$ content in all groups were observed $(P<0.001 ;$ Fig. 3$)$. In the control group, Na level in cerebellum + brainstem was higher than the left hemisphere $(P<0.01)$ and significantly increased in the left hemisphere compared to the right hemisphere $(P<0.01)$. In the PTZ and $\mathrm{Zn}$ group, Na concentration of the left hemisphere increased compared to the right hemisphere $(P<0.01)$. In the $\mathrm{Zn}$ group, Na concentration of the left hemisphere increased compared to the cerebellum+brainstem $(P<0.05)$. In the $\mathrm{Zn}$ and $\mathrm{Zn}+\mathrm{PTZ}$ groups, Na concentration of cerebellum + brainstem region increased compared to the right hemisphere $(P<0.05$; Fig. 3$)$.

A significant reduction of $\mathrm{Mg}$ content in all the brain regions was observed in $\mathrm{Zn}$-treated groups compared to other groups $(P<0.001$; Fig. 4$)$. Mg level was found high in the cerebellum+brain stem when compared to cerebral hemispheres and found high in the right hemisphere in the PTZ group $(P<0.05$ and $P<0.01)$.

In the $\mathrm{Zn}$-treated group, $\mathrm{Mg}$ level in the right hemisphere increased compared to the left hemisphere and the cerebellum+brainstem $(P<0.05$ and $P<0.01)$. In the $\mathrm{Zn}+\mathrm{PTZ}$ group, $\mathrm{Mg}$ concentration of the left hemisphere was higher

Table 1 Before and after PTZ, values of arterial blood pressure for experimental groups

\begin{tabular}{llllll}
\hline Groups & $n$ & $\begin{array}{l}\text { Diastolic pressure }(\mathrm{mmHg}) \\
\text { Before PTZ }\end{array}$ & $\begin{array}{l}\text { Systolic pressure (mmHg) } \\
\text { Before PTZ }\end{array}$ & $\begin{array}{l}\text { Diastolic pressure (mmHg) } \\
\text { After PTZ }\end{array}$ & $\begin{array}{l}\text { Systolic pressure (mmHg) } \\
\text { After PTZ }\end{array}$ \\
\hline Control & 8 & $80 \pm 3$ & $100 \pm 5$ & - & - \\
PTZ & 8 & $72 \pm 2$ & $92 \pm 6$ & $148 \pm 9$ & $170 \pm 10$ \\
Zn & 8 & $76 \pm 5$ & $96 \pm 8$ & - & - \\
Zn+PTZ & 8 & $88 \pm 4$ & $108 \pm 3$ & $142 \pm 9$ & $152 \pm 12$ \\
\hline
\end{tabular}

$* P<0.001$, significant difference from control group 


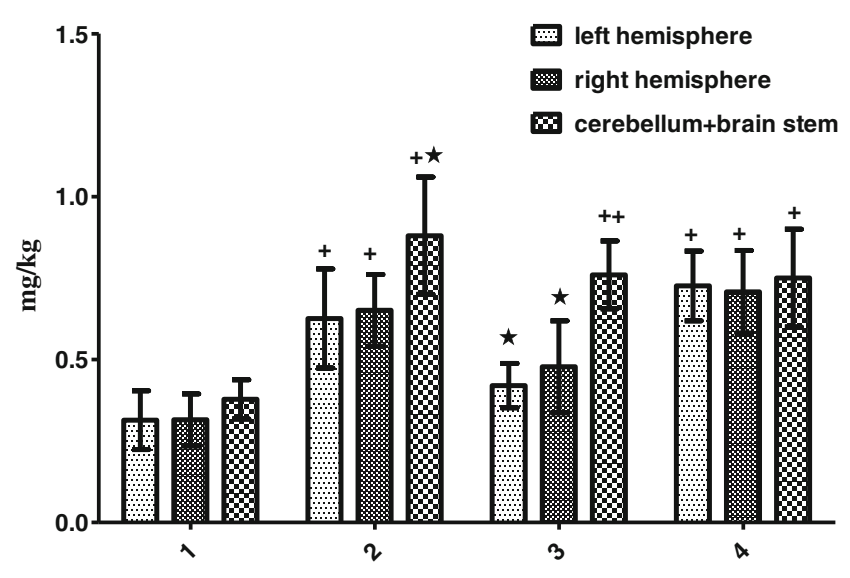

Fig. 1 Displaying Evans Blue (EB) amounts in the left and right hemispheres and cerebellum+brain stem of the groups and within groups (control group 1, PTZ group 2, Zn group 3, $\mathrm{Zn}+\mathrm{PTZ}$ group $4)$. One star shows a significant difference $(P<0.05)$. One cross shows a significant difference $(P<0.01)$. Control vs. other groups and the region of the brain within groups

than the right hemisphere $(P<0.05$; Fig. 4$)$. $\mathrm{Cu}$ content in all the brain regions was significantly decreased in all groups compared to the control $(P<0.01$ and $P<0.001$; Fig. 5).

In the control group, $\mathrm{Cu}$ concentration of cerebellum + brainstem increased compared to cerebral hemispheres $(P<$ 0.01 and $P<0.001)$. In the $\mathrm{Zn}$ group, $\mathrm{Cu}$ concentration of the right hemisphere increased compared to the cerebellum+ brainstem region $(P<0.05$ and $P<0.01)$. Cu concentration of the left and right hemispheres increased compared to the cerebellum+brainstem regions in $\mathrm{Zn}+\mathrm{PTZ}$ group $(P<0.05)$.

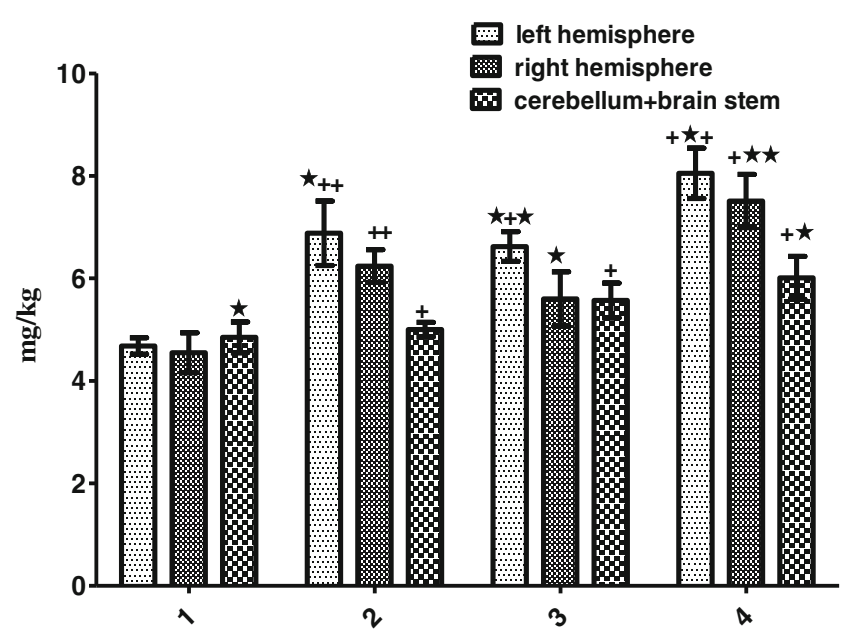

Fig. 2 Amounts of $\mathrm{Zn}$ (milligrams per kilogram tissue) in samples of the left brain hemisphere, right hemisphere, and cerebellum + brainstem regions in groups $1-4$ of experimental rats and within groups (control group 1, PTZ group 2, Zn group 3, Zn+PTZ group 4). Intragroup means \pm SD are shown. One cross shows a significant difference $(P<$ $0.01)$. One star shows a significant difference $(P<0.05)$. Control vs experimental groups. $\mathrm{Zn}+\mathrm{PTZ}$ group vs $\mathrm{Zn}$ and $\mathrm{PTZ}$ group and the region of the brain within groups

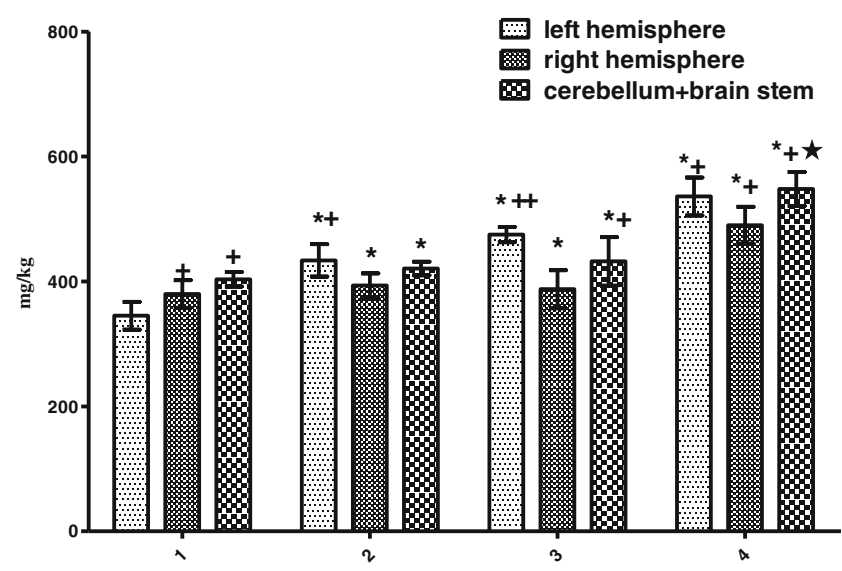

Fig. 3 Amounts of $\mathrm{Na}$ (milligrams per kilogram tissue) in samples of the left brain hemisphere, right hemisphere, and cerebellum + brainstem regions in groups $1-4$ of experimental rats and within groups (control group 1, PTZ group 2, Zn group 3, Zn+PTZ group 4). Intragroup means \pm SD are shown. One asterisk shows cases of significant differences $(P<0.001)$ One cross shows a significant difference $(P<0.01)$. Control vs experimental groups. $\mathrm{Zn}+\mathrm{PTZ}$ group vs $\mathrm{Zn}$ and PTZ group and the region of the brain within groups

\section{Discussion}

In our study, we observed that BBB permeability significantly increased in the PTZ group as shown in numerous studies [18]. We found that BBB breakdown is significantly higher than cerebral hemispheres. Arnaiz et al. [19] showed that the cerebellum is more susceptible to epileptic seizures, and its antioxidant capacity is lower than cerebral cortex, and brain imaging studies in human have shown that cerebral metabolic rate of glucose consumption is high in the occipital cortex and cerebellum The increased metabolism

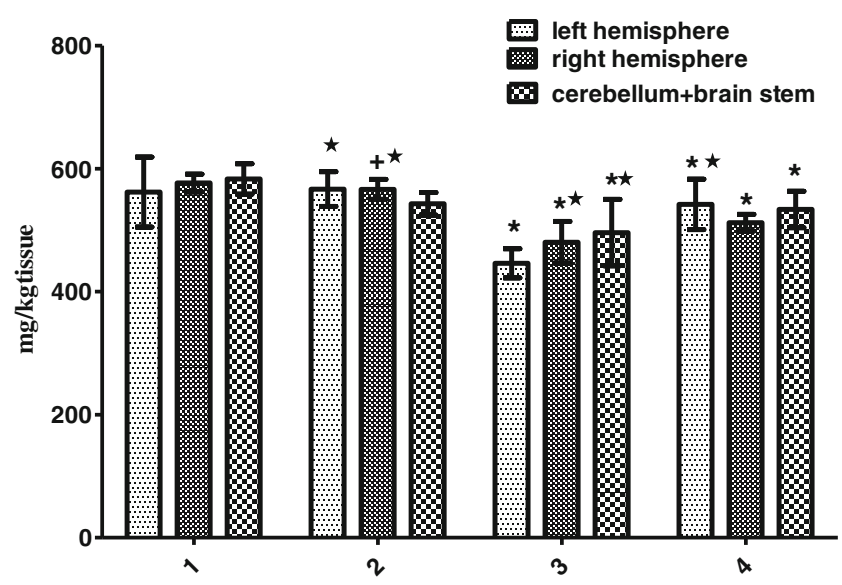

Fig. 4 Amounts of $\mathrm{Mg}$ (milligrams per kilogram tissue) in samples of the left brain hemisphere, right hemisphere, and cerebellum+ brainstem regions in groups $1-4$ of experimental rats (control group 1, PTZ group 2, Zn group 3, Zn+PTZ group 4) and within groups. Intragroup means $\pm \mathrm{SD}$ are shown. One asterisk shows cases of significant differences $(P<0.001)$ Control vs experimental groups and the region of the brain within groups 


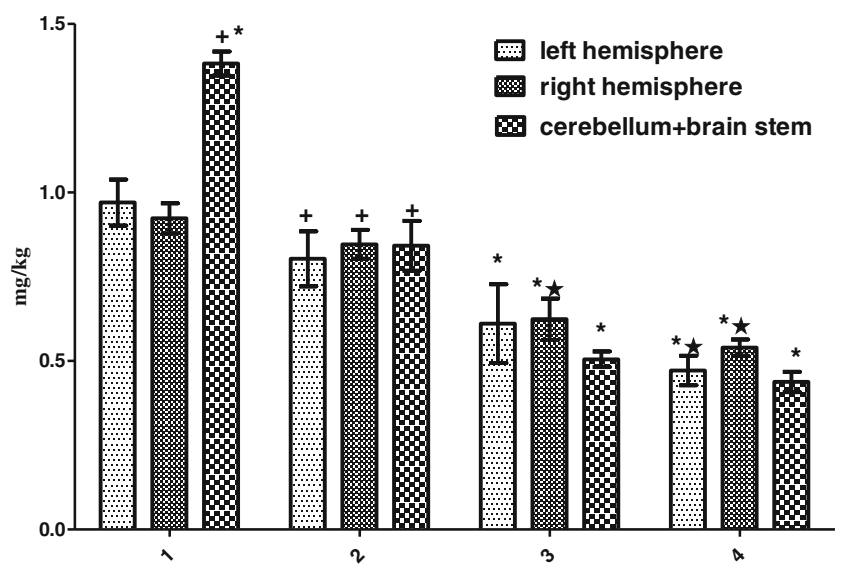

Fig. $5 \mathrm{Cu}$ (milligrams per kilogram tissue) in samples of the left brain hemisphere, right hemisphere, and cerebellum+brainstem regions in groups $1-4$ of experimental rats (control group 1, PTZ group 2, Zn group $3, \mathrm{Zn}+\mathrm{PTZ}$ group 4$)$ and within groups. Intragroup means $\pm \mathrm{SD}$ are shown. One asterisk shows cases of significant differences $(P<$ $0.001)$ One cross shows a significant difference $(P<0.01)$. Control vs experimental groups and the region of the brain within groups

caused by high firing rates of the cerebellum neurons may provoke more free radical production during epileptic seizures. These factors can be a reason for high Evans Blue values in comparing to brain hemispheres in the PTZ group [19].

Also, chronic $\mathrm{Zn}$ supplementation for 2 months increased BBB permeability during convulsions. These results demonstrated that BBB was severely damaged in both $\mathrm{Zn}-$ supplemented and not supplemented epileptic animals. Several reports suggested that the body electrolytes $\mathrm{Na}^{+}, \mathrm{K}^{+}$, $\mathrm{Ca}^{2+}$, and $\mathrm{Mg}^{2+}$ and the level of some trace elements play a vital role for seizure conditions to develop [20, 21]. It is known that $\mathrm{Zn}$ is a vital nutrient, and with the exception of iron, it is the most abundant trace element in the body. $\mathrm{Zn}$ released from neuron terminals serves a neuromodulatory function, as suggested by the multiple selective actions of $\mathrm{Zn}$ on synaptic function and the potency of $\mathrm{Zn}$ ions to modulate numerous neurotransmitter receptors such as GABA, NMDA, and ion channels [5, 9, 22]. As a potential neuromodulator, $\mathrm{Zn}$ is capable of exerting effects that could either inhibit or promote neuronal excitability, suggesting the possibility of both pro- and anti-convulsant effects [23, 24]. In this study, $\mathrm{Zn}$ supplementation for 2 months did not show a protective effect on increased BBB permeability during convulsions. Moreover, there was no change in severity and duration of seizure intensity and arterial blood pressure between animals treated with $\mathrm{Zn}$ and those that were not treated with $\mathrm{Zn}$. In parallel with our results, mice that are lacking vesicular $\mathrm{Zn}$ (pharmacologically or genetically) or rats that are fed a Zn-deficient diet have been shown to be more susceptible to kainate-induced seizures and show an increase in seizure severity and duration [25]. Conversely, intracerebral or intrahippocampal injections of
Zn have been shown to cause partial and secondarily generalized seizures in rabbits $[26,27]$. Taken together, these data indicate that alterations of $\mathrm{Zn}$ homeostasis contribute to the development of epileptic seizures. These contradictions are probably related to the fact that $\mathrm{Zn}$ manifests dissimilar effects depending on the type of application form, doses, and duration.

We found that $\mathrm{Zn}$ by itself also caused BBB breakdown without seizures. We think that $\mathrm{Zn}$ might cause an imbalance between ionic homeostasis in the brain. Significant increases of $\mathrm{Zn}$ amount in all brain regions under study were observed in all groups compared to the control group. Moreover, $\mathrm{Zn}$ concentration significantly increased in the $\mathrm{Zn}+\mathrm{PTZ}$ group compared to PTZ and Zn groups. Studies in hippocampus, amygdale, and neocortex showed that the neurons in these regions represent a group of excitatory gluzinergic neurons neurons It has been shown that most of the $\mathrm{Zn}$ in these $\mathrm{Zn}$-enriched neurons are found in their presynaptic boutons $[7,8]$. In addition to $\mathrm{Zn}$ released from neuron terminals, chronic $\mathrm{Zn}$ treatment may cause $\mathrm{Zn}$ accumulation. In our results, there is a correlation between $\mathrm{Zn}$ levels and Evans blue values in PTZ and $\mathrm{Zn}+\mathrm{PTZ}$ groups. According to this result, $\mathrm{Zn}$ accumulation may provoke BBB breakdown during epileptic seizures. $\mathrm{Zn}$ is a potent Na-K-ATPase inhibitor. Barbeau et al. showed that intracerebroventricular Zn inhibited Na-K-ATPase and resulted in convulsions by increasing cerebrospinal fluid potassium levels [27]. Inhibiting Na-K-ATPase in cerebral endothelial cells may be a significant reason for BBB damage.

On the other hand, we found a significant decrease in $\mathrm{Cu}$ levels in all experimental groups. $\mathrm{Cu}$ is an essential trace element in all living organisms. It is mainly a part of the active center of cuproenzymes, such as cytochrome c oxidase - a component of the mitochondrial respiratory chain [28]. One of the symptoms of $\mathrm{Cu}$ deficiency includes decreased superoxide dismutase, ceruloplasmin as well as cytochrome-c oxidase [29]. During epileptic seizures, free radical production is increased and insufficiency in antioxidant defence mechanisms could provoke BBB breakdown and neuronal damage. Sahin et al. [30] have shown decreased levels of $\mathrm{Cu}$ and $\mathrm{Fe}$ in brain tissue and increase in BBB permeability in the repeated seizures group. It has been shown that taking large doses of supplemental $\mathrm{Zn}$ over extended periods of time has shown to be associated with $\mathrm{Cu}$ deficiency [31]. These findings are parallel with our results. When we consider that free radical levels are increased in epileptic seizures, the antioxidant defense system in epileptic animals might remain insufficient in these groups because of $\mathrm{Cu}$ deficiency.

We found a significant increase in the amount of $\mathrm{Na}$ in the three brain regions of all the groups. Also, it was found that $\mathrm{Na}$ level was increased in the $\mathrm{Zn}+\mathrm{PTZ}$ group compared to the PTZ and Zn groups. It was shown that brain shrinkage 
induced by hypernatremia can cause rupture of cerebral veins, with focal intracerebral and subarachnoid hemorrhages, which in turn can provoke seizures [32]. Seizures also occur in $\leq 40 \%$ of patients treated for severe hypernatremia by rapid infusion of hypotonic solutions [33]. In our study, $\mathrm{Mg}^{2+}$ was unaltered in all brain regions in the PTZ group, and this is consistent with many studies [34]. $\mathrm{Mg}^{2+}$ is essential in neuronal excitability. It alters $\mathrm{Ca}^{2+}$ mobilization and stabilizes excitable membranes and also exerts a voltage-dependent blockage of the NMDA-receptor channel [35]. In human beings hypomagnesemia is associated with manifestations of central nervous system dysfunction [36]. $\mathrm{Mg}^{2+}$ levels in all the brain regions were decreased in the $\mathrm{Zn}$ group and $\mathrm{Zn}+\mathrm{PTZ}$ groups compared to other groups. Decreased $\mathrm{Mg}^{2+}$ level may contribute to BBB damage.

During convulsions, $\mathrm{Zn}$ treatment did not show a protective effect on the BBB permeability. Also, we have shown that $\mathrm{Zn}$ has adverse effects on the $\mathrm{BBB}$ via changing $\mathrm{Mg}$, $\mathrm{Cu}, \mathrm{Na}$, and $\mathrm{Zn}$ levels. Chronic $\mathrm{Zn}$ treatment by itself decreased $\mathrm{Mg}$ and $\mathrm{Cu}$ concentration and increased $\mathrm{Na}$ levels in brain tissue and during seizures and non-seizures. As a result of that, changes in prooxidant/antioxidant balance and neuronal membrane excitability may contribute to BBB damage. Our study showed that $\mathrm{Zn}$ treatment showed proconvulsant activity during seizures.

There is a neurochemical asymmetry as well as functional asymmetry in the brain [37]. It may be the underlying reason for difference in element levels in the control group. However, there are more fluctuations in element levels in the experimental groups. Brain hemispheres manifest different neurochemical changes against either extra supplementation of an element such as $\mathrm{Zn}$ or a pathological condition such as epilepsy. These neurochemical changes also affect element levels important for electrical activity of the brain. The cause of these differences can be revealed more precisely by molecular studies.

Open Access This article is distributed under the terms of the Creative Commons Attribution License which permits any use, distribution, and reproduction in any medium, provided the original author(s) and the source are credited.

\section{References}

1. Persidsky Y, Ramirez SH, Haorah J, Kanmogne G (2006) Bloodbrain barrier: structural components and function under physiologic and pathologic conditions. J Neuroimmune Pharmacol 1 (3):223-236. doi:10.1007/s11481-006-9025-3

2. Yorulmaz H, Seker FB, Oztas B (2011) Effect of vitamin E on blood-brain barrier permeability in aged rats with PTZ-induced convulsions. Neurophysiology 349-353. doi:10.1007/s11062-0119168-6
3. Hamed SA, Abdellah MM (2004) Blood levels of trace elements, electrolytes, and oxidative stress/antioxidant systems in epileptic patients. J Pharmacol Sci 96:349-359. doi:10.1254/ jphs.FPJ04032X

4. Carl GF, Critchfield JW, Thompson JL, McGinnis LS, Wheeler GA, Gallagher BB, Holmes GL, Hurley LS, Keen CL (1989) Effect of kainate-induced seizures on tissue trace element concentrations in the rat. Neuroscience 33(1):223-227. doi:10.1016/ 0306-4522(89)90323-0

5. Takeda A, Tamano H, Ogawa T, Takada S, Ando M, Oku N, Watanabe M (2012) Significance of serum glucocorticoid and chelatable $\mathrm{Zn}$ in depression and cognition in zinc deficiency. Behav Brain Res 226(1):259-64. doi:10.1016/j.bbr.2011.09.026

6. Parkin G (2004) Chemistry. Zinc-zinc bonds: a new frontier. Science 305:1117-1118. doi:10.1126/science. 1102500

7. Slomianka L (1992) Neurons of origin of zinc-containing pathways and the distribution of zinc-containing boutons in the hippocampal region of the rat. Neuroscience 48(2):325-352. doi:10.1016/0306-4522(92)90494-M

8. Frederickson CJ, Moncrieff DW (1994) Zinc-containing neurons. Biol Signals 3(3):127-139. doi:10.1159/000109536

9. Danscher G, Jo SM, Varea E, Wang Z, Cole TB, Schrøder HD (2001) Inhibitory zinc-enriched terminals in mouse spinal cord. Neuroscience 105(4):941-947. doi:10.1016/S0306-4522 (01)00243-3

10. Birinyi A, Parker D, Antal M, Shupliakov O (2001) Zinc colocalizes with GABA and glycine in synapses in the lamprey spinal cord. J Comp Neurol 30:433(2):208-221. doi:10.1002/ cne. 1136

11. Christine CW, Choi DW (1990) Effect of zinc on NMDA receptor mediated channel currents in cortical neurons. J Neurosci 10:108116

12. Sterman MB, Shouse MN, Fairchild MD, Belsito O (1986) Kindled seizure induction alters and is altered by zinc absorption. Brain Res 383:382-386. doi:10.1016/0006-8993(86)90045-4

13. Itoh M, Ebadi M (1982) The selective inhibition of hippocampal glutamic acid decarboxylase in zinc-induced epileptic seizures. Neurochem Res 7:1287-1294. doi:10.1007/ BF00965899

14. Lynes MA, Kang YJ, Sensi SL, Perdrizet GA, Hightower LE (2007) Heavy metal ions in normal physiology, toxic stress, and cytoprotection. Ann N Y Acad Sci 1113:159-172. doi:10.1196/ annals.1391.010

15. Naziroglu M (2007) New molecular mechanisms on the activation of TRPM2 channels by oxidative stress and ADP-ribose. Neurochem Res 32:1990-2001. doi:10.1007/s11064-007-9386-x

16. Oztas B, Akgul S, Seker FB (2007) Gender difference in the influence of antioxidants on the blood-brain barrier permeability during pentylenetetrazole-induced seizures in hyperthermic rat pups. Biol Trace Elem Res 118:77-83. doi:10.1007/s12011-0070020-1

17. Dani V, Malhotra A, Dhawan D (2007) 131I induced hematological alterations in rat blood: protection by zinc. Biol Trace Elem Res 120(1-3):219-226. doi:10.1007/s12011-007-8027-1

18. Oztas B, Kaya M (2003) Blood-brain barrier permeability during acute and chronic electroconvulsive seizures. Pharmacol Res 48 (1):69-73

19. Arnaiz L, Lores S, Travacio M, Llesuy ZS, Rodriguez de G (1998) Regional vulnerability to oxidative stress in a model of experimental epilepsy. Neurochem Res 23(12):1477-1483

20. Sheth DP (1997) Hypocalcemic seizures in neonates. Am J Emerg Med 15:141-143. doi:10.1016/S0735-6757(97)90176-5

21. Ilhan A, Uz E, Kali S, Var A, Akyol O (1999) Serum and hair trace elements levels in patients with epilepsy and healthy subjects: does the antiepileptic therapy affect the element concentrations of hair. Eur J Neurol 6:705-709. doi:10.1046/j.1468-1331.1999.t01-1660705.x 
22. Hollman M, Boulter J, Maron C, Beasley L, Sullivan J, Pecht G, Heinemann S (1993) Zinc potentiates agonist-induced currents at certain splice variants of the NMDA receptor. Neuron 10:943-954. doi:10.1016/0896-6273(93)90209-A

23. Harrison NL, Gibbons SJ (1994) $\mathrm{Zn}^{+2}$ : an endogenous modulator of ligand and voltage-gated ion channels. Neuropharmacol 33:935-952. doi:10.1016/0028-3908(94)90152-X

24. Fukahori M, Itoh M, Oomagari K, Kawasaki H (1988) Zinc content in discrete hippocampal and amygdaloid areas of the epilepsy (El) mouse and normal mice. Brain Res 455:381-384. doi:10.1046/j.1471-4159.2003.01803.x

25. Takeda A, Hirate M, Tamano H, Nisibaba D, Oku N (2003) Susceptibility to kainate-induced seizures under dietary zinc deficiency. J Neurochem 85:1575-1580. doi:10.1046/j.14714159.2003.01803.x

26. Pei Y, Zhao D, Huang J, Cao L (1983) Zinc-induced seizures: a new experimental model of epilepsy. Epilepsia 24:169-176. doi:10.1111/j.1528-1157.1986.tb03526.x

27. Barbeau A, Donaldson J (1974) Zinc, taurine and epilepsy. Arch Neurol 30:52-58

28. Puig S, Thiele DJ (2002) Molecular mechanisms of copper uptake and distribution. Curr Opin Chem Biol 6:171-180. doi:10.1016/ S1367-5931(02)00298-3

29. Sandstead HH (1995) Requirements and toxicity of essential trace elements, illustrated by zinc and copper. Am J Clin Nutr 61:621-624

30. Sahin D, Ilbay G, Ates N (2003) Changes in the blood-brain barrier permeability and in the brain tissue trace element concentrations after single and repeated pentylenetetrazoleinduced seizures in rats. Pharmacol Res 48:69-73. doi:10.1016/ S1043-6618(03)00056-2

31. Ogiso T, Moriyama K, Sasaki S, Ishimura Y, Minato A (1974) Inhibitory effect of high dietary zinc on copper absorption in rats. Chem Pharm Bull (Tokyo) 22:55-60

32. Adrogue HJ, Madias NE (2000) Hypernatremia. New Eng J Med 342:1581-1589

33. Reeves WB, Bichet DG, Andreoli TE (1998) William's textbook of endocrinology. In: Wilson JD, Foster DW, Kronenberg HM, Larsen PR (eds) Posterior pituitary and water metabolism, 9th edn. Saunders, Philadelphia, pp 341-372

34. Kürekçi AE, Alpay F, Tanindi S, Gokcay E, Ozcan O, Akin R (1995) Plasma trace element, plasma glutathione peroxidase, and superoxide dismutase levels in epileptic children receiving AEDs therapy. Epilepsia 36:600-604. doi:10.1111/j.15281157.1995.tb02574.x

35. Agus Z, Wasserstein A, Goldfarb S (1982) Disorders of calcium and magnesium homeostasis. Am J Med 72:473-488. doi:10.1016/ 0002-9343(82)90519-8

36. Czeh G, Somjen GG (1989) Changes in extracellular calcium and magnesium and synaptic transmission in isolated mouse spinal cord. Brain Res 486:274-285. doi:10.1016/0006-8993 (89)90513-1

37. Glick SD, Shapiro KM (1984) Functional and neurochemical asymmetries. In: N. Geschwind A.M. Galaburda (eds) Cerebral dominance. Academic Press, New York, pp 147-166 